\title{
LANGUAGE NO BAR IN HINDI SOAP OPERA- A STUDY
}

\author{
Dr. Sonia Hooda \\ Assistant Professor, Department of Communication and Media Technology, \\ J.C. Bose University of Science and Technology YMCA, Faridabad
}

Article DOI: https://doi.org/10.36713/epra9487 DOI No: 10.36713/epra9487

\begin{abstract}
Television is the important source of information education and entertainment in Indian society. This reflects social reality in real time. Some stereotypes of society have also been showed by Indian television. It can be seen that use of regional languages in Hindi serials are increasing day by day and there is no language bar in Hindi TV serials. Inter regional migration the reason behind this phenomenon. Rapid increase of this language glued more people to TV sets. In the COVID crisis when people are forced to sit at home they have nothing to do and most importantly they don't go outside they had only one option in the context of Info edutainment and it was Television. This also increased the viewership of Hindi serials. Current study is about to find out the actual reason to use this language and situation would have also seen in which particular verbatim and satires are going to be used. This research paper also study the content of Hindi soap opera in which rapidly accelerating linguistic change has been noted. This research paper is based on a comparative study and content analysis study between top three Hindi serial according to TRP to show the regional language used and is that language the reason to reach top.
\end{abstract}

KEYWORDS: Regional Language, Satires, Situation, Verbatim, linguistic change, content

\section{INTRODUCTION}

Television was the first broadcast in Delhi on September 15, 1959. All might be stunned to know that television actually began as an experiment. Years later, its daily transmission finally began in 1965 as a part of All India Radio (AIR). Since then, the Television industry has seen immense growth. After this magical wand of entertainment was introduced, we have never settled down. Once television came into Indian existence, and then came its colorful version.

In the year 1982, color television transmission telecast was introduced for the first time which brought the layer of joy among Indians. Seeing human beings move inside a cabinet was quite entertaining and joyful for Indian audiences back then since the technology was still relatively new.

Indian small screen programming started off in the early 1980s. During this time, there was only one national channel, the government-owned Doordarshan. By the 1970s several television centers opened in other parts of the country as well.

The early programs of these experimental broadcasts were generally educational programs for school children and farmers. But later in the 1990s television faced revolutionary changes. The advent of private channels started in India one by one. Following CNN's broadcast of The Gulf War, STAR (-a satellite television company based in Hong Kong and Asia) entered the Indian media, followed soon thereafter by ZEE TV.
From the 1960s through the 1990s, DD, the Government of India's public service broadcaster, was the only source of amusement for decades. However, this network aired many documentaries and public service programs. In the year 1984 drama Hum Log (We the People), became to define family time. Hum Long aired its final episode almost exactly 34 years ago. In addition to the fact that the Hum Log premiered on Indian television, the fact that it was produced during a time of tremendous social, technological, and economic change greatly influenced its perception and resonance.

Today, traditional TV sets are being replaced with laptop or smart TV screens as a result of technology. Well, who knew that Cinemas will become so common that every 2 Indian household has dish connections now. By analyzing the Indian cinema revolution, we can understand how television has taken on new meanings.

India is home to 130 crore people speaking 22 recognized languages and hundreds of other unrecognized mother tongues and dialects. Every business including entertainment media comprehends the importance of vernacular languages. Due to inter-state immigration, we can-not define a language by its state, not anymore. While if we look at it from the perspective of entertainment, immigration is also pursuing people to watch television, be it any form of entertainment, daily soaps, movies, or web series. Indians are inquisitive, they want to try every 
genre of entertainment in their comfort language or I must say their regional language.

Well, in this research paper researcher is going deep into discussion, basically, analyzing the content, verbalizes, and slang that is used in Indian soap operas. After days of observations and studies, detailed report of regional language has been created. What are some aspects of localization and more so. This is a great opportunity to learn about Indian cinema from scratch to everything now. During COVID-19 when people were sitting at home because they had no option to go outside they sit in-front of the television sets and watch Hindi serials, movies, series etc. For this purpose researcher selected top three Hindi television serials on the basis of BARC (Broadcast Audience Research Council of India) report. When the researcher decided to study on the same topic that week BARC releases his report of $3^{\text {rd }}$ week according to which most viewed Hindi channel was Start Plus and top three Hindi serials were Anupama, Ghum Hai Kisikey Pyaar Mein, Imlie. In these serials, use of particular language can be seen. In this study researcher wants to find out the regional terms used in Hindi serials or we can say slang language, how many times they are using it and what are their meaning and in which situation these particular terms are using. In this paper nature of verb in that particular language is would be discussed.

\section{BRIEF STORYLINES OF THE SERIALS}

\section{Anupama}

Anupama is the story of a Gujarati family. In which in the lead role is a simple housewife Anupama who is taken for granted even after she does so much work for the family. She is less educated and doesn't know a word of English. She is also not able to mix up with the top elite group ladies in society. However, she is a great cook and works for the family without any complaint. Her two kids, Paritosh and Pakhi feel ashamed of her as their mother but Samar respects and love his mother a lot. The story continues when Vanraj, a self-absorbed and egoistic man, decides to get married to his girlfriend Kavya on the same day of their wedding anniversary. Anupama catches him redhanded and refuses to forgive him. She breaks all ties with Vanraj but continues to stay in Shah house for her family. Soon Vanraj is forced to leave the house and he takes Pakhi along. A series of fights and drama finally leads to Vanraj and Anupama being civil to each other for the peace and happiness of their daughter Pakhi. Anupama serial is an outstanding blend of simplicity and scenic beauty. The show shares all kinds of emotions starting from happiness to sorrows and laughter. The light moments with Baa, Bapuji, and Mamaji make the serial even more delightful to watch. Rajan Shahi brings a fresh new story and there no flaw in the depiction as well. Rupali Ganguly and Sudhanshu Pandey are great with their respective roles. The portrayal of youngsters like Samar, Paritosh, Pakhi, Kinjal, and Nandini brings a youthful twist to the serial.
Overall the serial is a mixture of all the aspects that a family drama needs. Language used in this serial is a mixture of Hindi and Gujarati.

\section{Ghum Hai Kisikey Pyaar Mei}

This story is about the Marathi family. Follow the culture of maratha's and use a language of mixture of Hindi and Marathi. Gum Hai Kisi Ke Pyaar Mein serial portrays the love triangle between Virat, Pakhi, and Sayi. Gum Hai KisiKe Pyaar Mein serial essays the tough choice Virat has to make between his love and duty and is forced to get married to Sayi under certain circumstances. Sayi's father dies and takes a promise from Virat to take care of his daughter always. However, Virat has always been in love with Pakhi but can't break his promise as well. The audience of Gum Hai Kisi Ke Pyar Mein can also enjoy the interesting new story of Virat, Pakhi, and Sayi whose life take a drastic change with just one decision made by Virat. Here in this article, we are sharing the information about the cast and crew, production team, story, gossips, and spoilers, twists \& turns of the Ghum Hain Kisi Ke Pyaar Mein serial. The story of Ghum Hai Kisikey Pyaar Mei revolves around a police inspector, Virat who has to make a tough choice and choose either love or his duty. This story shows the love that Pakhi and Virat share even after years of separation. Sai's father and Virat's senior dies and before dying ask Virat to always protect his daughter.

\section{Imlie}

This serial's story revolves around the village situated in Uttar Pardesh. Language used in this serial is Indo-Aryan languages, central and East which includes Awadhi, Bhojpuri, Brajbhasha Khadi Boli etc. Imlie serial is the story of a village girl name Imlie (Imlie) who is proud to be a village girl and doesn't shy away from giving answers to village people. Imlie story is produced by Gul Khan and recently released its first promo of Imlie. The male lead will be played by Gashmeer Mahajani while Sumbul Touqeer will be seen in the role of the female lead. Imlie audience can enjoy the fun and unique love story of a city boy and village girl who have totally opposite personalities. The story of Imlie revolves around a village girl who never fails to impress anyone with her answers. Imlie story progresses as she meets with a city boy. The two form a close bond over the course of time being from different backgrounds. The girl wishes to change the mentality that village people are not all dumb and can be literate if given chance.

\section{REVIEW OF LITERATURE}

Today, there are over 600 million viewers in 146 million homes with television channels and a market estimated to be worth 588 billion INR (KPMG-India, 2016). There are specialized channels ranging from entertainment to sports, children, and news but the general- interest entertainment channels in Hindi and regional languages dominate the television market with around 55\% viewership (KPMG-India, 2016). The general entertainment channels space accounted for 8 out of 10 top 
primetime shows in 2016 (KPMG-India, 2017) of which familybased- soap-operas or serials form a major part. Soap-operas that began as weekly serials telecast on Doordarshan in the ' 80 's turned into daily serials with the entry of $24 * 7$ private television channels in the 90's. since then, the competition has been fierce in a fragmented market, rapid growth in the number of channels and regionalization, conversely. This leads to an increase in the number of soap-operas (Lecuyer,2013). The dynamic changes in Indian society resulted in the transformation of joint families to nuclear. Traditionally, India had a patriarchal family system with a few exceptions, which follow the matriarchal system (Rao, 2011) A consequence of such change was a large scale migration to urban areas and conversion of joint families to nuclear (Khan and Rizvi, 2015). The support system and the economic compulsions of keeping the family business intact are the prime reasons. However the extent of autonomy and democracy may vary from region to region, community to community and caste to caste, depending upon the degree of its adaptation of the modern values and the urban way of life (Mondal 2016).

Research Methodology: qualitative research method, Content analysis, observation method, participant analysis

Sample size: 3 serials (Anupama- 487 episodes, Ghum Hai Kisikey Pyaar Mein-422 episodes, Imlie- 380 episodes,)30 minutes duration each

Universe- Top 3 serials on the basis of BARC report

Population- Anupama, Ghum Hai Kisikey Pyaar Mein, Imlie

\section{CONTENT ANALYSIS}

\section{Anupama}

Tame kema cho- How are you

Manane mapha karo- sorry

Maru nama...chhe- My Name is

Mane khabara nathi - I Don't Know

Taru naam su che- What's Your Name

Thobo- Stop

Padharo-welcome

Mane khabar che- mujhe khabar hai

Saras che- Acha hai

After analysis researcher found that characters of this serial are using some words on regular basis. Characters are basically using Hindi language but some words they speaking in Gujarati only. Words like Taru naam su che, Padharo, Mane khabar che and Saras che etc. are using in common situation weather it is of happiness and weather it is of tension or in some odd situation. Frequency of using these words in a 30 minute episode is approximate $5-10 \%$.

\section{Ghum Hai Kisikey Pyaar Mein}

Kuthe - where
E kahe

Tu laaj tos ka

Ho-yes

Mi thik ahe- I'am good

Mast- HA-Mast- bhut badiya

Barr Ahey- Looking Good

Vadani Kawal Gheta- Have a Nice Meal

Mala samajate- I understand

Barobar- Exactly

Dado Sutho- Be Happy

After analysis, in this serial some words are using on regular basis. Characters basically using Hindi language but some words they speak in Marathi only. Like Kaku, Ayi, Tayi, Maushi, E Kahe, Kuthe, Barobar, Mi thik ahe etc. some slangs characters are using like mast ha mast, Dado sutho etc. just to attract viewer on that particular words and these two words are pet words of these two characters. Mast hai mast is a Positive connotation signifying that everything is well and fine but in this term connotation is being used to taunt also. Dado Sutto is the term hilariously used by women though it's a positive term but according to the situation this word is used in tone language. Frequency of using these words in a 30 minute episode is approximate $10-15 \%$.

\section{Imlie}

Ama yaar- Oh please

Apko swagat aeh- you are welcome

Tohar- Tumhara

Jaaiise- Jaise

Aapan- Apne

Jin Laya- Jink liye

Paricha- Exam

Hamka- Hume

Hmar papan- Hamara paap

Hamka ose Bachava- Hume usse bcahao

Saitan- shaitaan (Ghost)

After analysis researcher found that some characters those belongs to a village situated in Uttar Pradesh usually speaks mixture of Awadhi, Khadi Boli, Braj Bhasha etc. and some common words used by like Tohar, Jaaiise, Aapan, Jin Laya, Paricha, Hamka, Hmar etc. are the words which they use during conversation of everyone may be the reason behind is this language is their native language. As an observer researcher understood that some words of this language is tough for a layman.

\section{CONCLUSION}

- Research found that Reason behind of using regional language in Hindi serials are accelerating rate of inter region immigration of the people which helps to increase their interest in particular language.

- To use particular regional words like Dado-Sutto, Mast-Ha-Mast, Godu, Hum keht Rahe, or to say three meanings of the same word, Manane mapha karo there 
are verbatim, slangs used by characters to make that particular situation interesting.

- Analysis also says that regional people also wants to see the content in regional language so that they can connect to character in their real life

- Research says that globalization has also had an effect on the thinking and interest of the viewer.

- The reason behind some particular words to say is only to attract viewer attention and after some time that slangs found on the tongue of the people this is also a strategy of the script writer to shift the attention of the viewer

- Situation has also found a big factor in using regional language words. There are some selection of words and according to the situation only those words are recite by characters.

- Analysis revealed that some particular slangs given to the character like Dado-Sutto etc. and it means be happy but use of this slang is used in taunt tone also. So situation plays an important role.

- An analysis can be seen that to attract a particular linguistic people towards that particular serial just because to enhance the popularity of that regional language among such people of a particular region.

- Sometimes some phrases in Gujarati, Marathi and in Brij Bhasha or in khadi Boli used in some happy situation just to express happiness and sometimes some verbatim Used to express anger.

- There is one more reason to spread these regional languages to Non Hindi to Hindi people and people came to know about some common words of such language and use these words in their daily life. Words like Aayi, Baa, Bapuji, padharo these are some common phrases a layman can learn or make a vocabulary of some of these common words.

\section{REFERENCES}

1. Bajpai, Shailaja (2016) The world came home: History of television in India, The Indian Express, July 24, www.indianexpress.com

2. Broadcast Audience Research Council India (2017) Television audience measurement description of methodology, www.barcindia.co.in

3. Dundoo, Sangeetha Devi (2012) TV turn to southern remakes, The Hindu, February 12,www.thehindu.com

4. Gillespie, Marie, Cheesman, Tom (2002) Media cultures in India and the South Asian diaspora, Contemporary South Asia, 11(2):pp.18-24, London: Routledge.

5. KPMG India (2017) Indian Media and Entertainment Industry Annual Report, FICCI, New Delhi, India, www.google.com

6. Roy, Tasmayee Laha and Gaurav Laghate (2016) How regional channels are catching with local versions and attracting advertisers, The Economic Times, April 23, www.economictimes.indiatimes.com
7. Sathyaprakash $M R$ and Ravi, B $K$ (2011) Understanding transnational television in India, International Journal of South Asian Studies, 4(1):114-129.

8. Sen, Sukomal (2000) Globalization of culture- to what end?' The Marxist, 16(2):AprilJune, New Delhi, India.

9. Sinclair, J. and Harrison, M. (2004) Globalization, Nation and Television in Asia: The Cases of India and China, Television and New Media, 5(1):41-54.

10. Shashi Kaul \& Shradha Sahni (2010), Portrayal of in Television(TV) Serials. Stud Homecomm sci, vol.4 (1).p.1520. 